\title{
Effects of hydrofluoroalkane and dry powder- formulated corticosteroids on sputum inflammatory markers in asthmatic patients
}

\author{
Hans-Peter Hauber MD ${ }^{1}$, Rame Taha $\mathrm{MD}^{1}$, Celine Bergeron MD MSc${ }^{1}$, Vladimir Migounov MD², \\ Qutayba Hamid MD PhD ${ }^{1}$, Ron Olivenstein $\mathrm{MD}^{1,3}$
}

\begin{abstract}
H-P Hauber, R Taha, C Bergeron, V Migounov, Q Hamid, R Olivenstein. Effects of hydrofluoroalkane and dry powderformulated corticosteroids on sputum inflammatory markers in asthmatic patients. Can Respir J 2006;13(2):73-78.
\end{abstract}

BACKGROUND: Inhaled corticosteroids are powerful drugs that can suppress airway inflammation in asthmatic patients. Deposition of most of the inhaled corticosteroid occurs mainly in the central airways. However, a new hydrofluoroalkane formulation of beclomethasone dipropionate (HFA-BDP) is preferentially deposited in the distal airways. Inflammatory characteristics of induced sputum have been shown to differ in samples collected early after sputum induction compared with later.

OBJECTIVE: To compare the effects of HFA-BDP and budesonide in a dry powder inhaler (DPI-BUD) on inflammatory cells and inflammatory cytokine expression in early and late induced sputa compared with placebo.

METHODS: Seventeen patients with mild, intermittent bronchial asthma were randomly assigned to two treatment groups: eight patients received HFA-BDP and nine patients received DPI-BUD. Each patient was treated with one of the active treatments and placebo (for four weeks), with a two-week washout interval in between. Inflammatory cells and expression of interleukin (IL)-4 and IL-5 were measured in early and late induced sputa before and after active treatment, as well as before and after placebo treatment using immunocytochemistry and in situ hybridization.

RESULTS: Compared with placebo, eosinophils were significantly reduced in both early and late induced sputa after HFA-BDP treatment $(\mathrm{P}<0.05)$, whereas DPI-BUD had a significant effect only on early induced sputum. Both HFA-BDP and DPI-BUD decreased IL-4 expression in early and late induced sputa, but the effect was more prominent with HFA-BDP. IL-5 expression was reduced in both early and late induced sputa after HFA-BDP treatment. DPI-BUD significantly decreased IL-5 expression in early but not in late induced sputum. The number of lymphocytes was not altered by either treatment. CONCLUSIONS: HFA-BDP reduced eosinophilic inflammation and $\mathrm{T}$ helper 2-type cytokine expression in both early and late induced sputa, whereas the effect of DPI-BUD on inflammation was predominantly demonstrated in early induced sputum.

Key Words: Beclomethasone dipropionate; Bronchial asthma; Budesonide; Eosinophils; Hydrofluoroalkane; Induced sputum

\section{Effets de l'hydrofluoroalcane et des corticostéroïdes en poudre sèche sur les marqueurs de l'inflammation dans les expectorations de patients asthmatiques}

HISTORIQUE : Les corticostéroïdes par inhalation sont des médicaments
puissants qui peuvent supprimer l'inflammation des voies respiratoires chez
les patients asthmatiques. La plupart des corticostéroïdes par inhalation se
déposent principalement dans les voies respiratoires centrales. Or, une nou-
velle préparation de dipropionate de béclométhasone à base d'hydrofluo-
roalcane (HFA-BDP) se dépose davantage dans leur portion distale.
L'analyse des caractéristiques inflammatoires des expectorations provoquées
a révélé des différences selon que le prélèvement d'échantillon était fait
plus ou moins longtemps après l'induction des expectorations. OBJECTIF : Comparer à ceux du placebo les effets du HFA-BDP et du budésonide par inhalation de poudre sèche (DPI-BUD) sur les cellules inflammatoires et l'expression des cytokines inflammatoires selon le temps écoulé avant le prélèvement des expectorations provoquées.

MÉTHODES : Dix-sept patients souffrant d'asthme intermittent bénin ont été assignés aléatoirement à l'un de deux groupes : huit ont reçu le HFA-BDP et neuf ont reçu le DPI-BUD. Chaque patient a été traité au moyen de l'un des deux médicaments actifs et du placebo (pendant quatre semaines) avec un intervalle de sevrage de deux semaines entre les deux. Les cellules inflammatoires et l'expression de l'interleukine (IL)-4 et de l'IL-5 ont été mesurées dans les expectorations induites recueillie précocement et tardivement, avant puis après le traitement actif, de même qu'avant et après le placebo, à l'aide de tests d'immunocytochimie et d'hybridation in situ. RÉSULTATS : Par rapport au placebo, les éosinophiles ont significativement diminué dans les expectorations induites recueillie précocement et tardivement après le HFA-BDP $(p<0,05)$, alors que le DPI-BUD a exercé un effet significatif uniquement sur les expectorations recueillie induites précocement. Le HFA-BDP et le DPI-BUD ont tous deux ralenti l'expression de l'IL-4 dans les expectorations recueillie induites précocement et tardivement, mais l'effet s'est révélé plus marqué avec le HFA-BDP. L'expression de l'IL-5 a diminué dans les expectorations recueillie induites précocement et tardivement, après le traitement par HFA-BDP. Le DPI-BUD a significativement diminué l'expression de l'IL-5 dans les expectorations recueillie induites précocement mais non dans les expectorations recueillie induites tardivement. Ni l'un ni l'autre des deux traitements n'ont modifié le nombre de lymphocytes.

CONCLUSION : Le HFA-BDP a réduit l'inflammation éosinophile et l'expression des cytokines des lymphocytes $\mathrm{T}$ auxiliaires de type 2 dans les expectorations recueillie induites précocement et tardivement, alors que l'effet du DPI-BUD sur l'inflammation a surtout été observé dans les expectorations recueillie induites précocement.

${ }^{1}$ Meakins-Christie Laboratories, McGill University, Montreal, Quebec; ${ }^{2} 3 \mathrm{M}$ Pharmaceuticals, London, Ontario; ${ }^{3}$ Montreal Chest Institute, Montreal, Quebec

Correspondence: Dr Qutayba Hamid, Meakins-Christie Laboratories, McGill University, 3626 St-Urbain Street, Montreal, Quebec H2X 2 P2. Telephone 514-398-3864, fax 514-398-7483, e-mail qutayba.hamid@mcgill.ca 
B ronchial asthma is a chronic inflammatory airway disease that is characterized by airway inflammation, bronchial hyperresponsiveness and mucus overproduction. Eosinophilic inflammation in bronchial asthma has been shown to be present in both the central and peripheral airways (1). Inhaled corticosteroids have been found to successfully suppress airway inflammation $(2,3)$. However, deposition of inhaled corticosteroids occurs mainly in the central airways (4). Due to their large particle size, chlorofluorocarbon (CFC)- and dry powder inhaler (DPI)-formulated corticosteroids are not very efficiently delivered to the lungs; for example, only $4 \%$ of the inhaled dose of CFC-formulated beclomethasone dipropionate (CFC-BDP) is deposited in the lungs, whereas $82 \%$ remains in the oropharynx (5). When budesonide is in a DPI formulation (DPI-BUD), $21 \%$ to $32 \%$ of the metred dose is deposited in the lungs $(6,7)$, but the deposition is predominantly central (6). New hydrofluoroalkane (HFA)-formulated steroids, such as HFA-BDP (QVAR [3M Pharmaceuticals, Canada]), have been reported to be delivered to the airways more effectively (53\%) and to be deposited preferentially in the distal airways (5). Moreover, it has been shown that HFA-BDP is effective in treating asthma and that only one-half of the dose is required compared with CFC-BDP $(8,9)$.

Induced sputum is a reliable, noninvasive method to examine inflammatory markers in the airways. It is increasingly used in the investigation of airway inflammation in bronchial asthma. A previous study has shown that the cellular profile of induced sputum differs in samples that are collected earlier (4 min) rather than later $(20 \mathrm{~min})$ after initiation of sputum induction (10). In that study, cells associated with airway secretions (eosinophils and neutrophils) were prominent in samples collected early after sputum induction, whereas cells associated with alveolar secretions (macrophages) were prominent in samples collected later, although eosinophils were also present in the late sample (10). We previously studied fractional analysis of induced sputum with 5 min intervals up to $15 \mathrm{~min}$ (11). We reported that the duration time of induced sputum collecting influences the inflammatory profile, with more eosinophils, interleukin (IL)-4 and IL-5 detected in the $10 \mathrm{~min}$ and $15 \mathrm{~min}$ samples. These data also showed that the timing of sputum collection after induction is crucial and may be reflective of differing representation between the central and the more peripheral airways.

The present study compared the effects of HFA-BDP with DPI-BUD on inflammatory markers in early and late inducedsputum samples. In comparing HFA-BDP with DPI-BUD, we examined two different inhaler devices that have been attributed the highest lung deposition rate. Moreover, a previous study (12) showed that HFA-BDP was as effective as DPI-BUD in providing asthma control at only one-half the daily dose. We hypothesized that the anti-inflammatory effect of HFA-BDP and DPI-BUD would be different in early and late induced-sputum samples due to the known profile of a more distal deposition of HFA-BDP.

\section{METHODS}

\section{Study design}

The study protocol was approved by the Ethics Committee Board of the Montreal Chest Institute, Montreal, Quebec. Seventeen mildly asthmatic patients who were only using short-acting beta-2-agonists were recruited. Patients were free of respiratory infection for at least three months. The study used a double-blind, placebo-controlled design. Patients were randomly divided into two groups. One group of patients received HFA-BDP $(n=8)$ and the other group received DPI-BUD $(n=9)$. All patients were treated with active treatment (HFA-BDP or DPI-BUD) for four weeks and with placebo for another four weeks, with a two-week washout interval in between in a random order (crossover design) (Figure 1). The doses of HFA-BDP (200 $\mu$ g twice daily) and DPI-BUD (400 $\mu \mathrm{g}$ twice daily) were chosen for their equipotency, as previously described $(8,12)$. Spirometry and sputum induction was performed before and after each of the four weeks of active treatment and placebo.

\section{Sputum induction and cytospin preparation}

Sputum induction was performed using a modification of the method of Pizzichini et al (13). Sputum samples were obtained $5 \mathrm{~min}$ (early induced sputum) and $15 \mathrm{~min}$ (late induced sputum) after sputum induction. Patients were administered salbutamol $(200 \mu \mathrm{g})$ to inhibit possible bronchoconstriction during sputum induction. Sputum was induced by a $4.5 \%$ hypertonic saline solution generated by a DeVilbiss ultrasonic nebulizer (Ultra-Neb99 [Sunrise Medical, USA]), and processed as previously described (13). Briefly, sputum was selected from the expectorate and a weighed aliquot was dispersed with four volumes of freshly prepared $0.1 \%$ dithiothreitol followed by four volumes of Dulbecco's phosphate buffer solution (PBS), after which, the dispersed sample was filtered through a $48 \mu \mathrm{m}$ nylon mesh. The sample was centrifuged at $300 \mathrm{~g}$ for $10 \mathrm{~min}$. The cell pellet was resuspended in PBS and the total cell count and the cell viability of the filtrate were measured using trypan blue exclusion, and cytospin preparations were made (Cytospin 3 cytocentrifuge [Shandon Southern Instruments, USA]).

For immunocytochemistry, the cytospins were briefly fixed in a solution of acetone:methanol (40:60), then air dried and stored at $-20^{\circ} \mathrm{C}$. For in situ hybridization, cytospins were air dried and fixed in $4 \%$ paraformaldehyde for $30 \mathrm{~min}$, then washed twice for $5 \mathrm{~min}$ with PBS, kept at $37^{\circ} \mathrm{C}$ overnight, and stored at $-80^{\circ} \mathrm{C}$ until needed.

\section{Immunohistochemistry}

To detect inflammatory cells, antibodies targeting major basic protein (MBP) (eosinophils), elastase (neutrophils), CD3 ( $\mathrm{T}$ cells) and CD68 (macrophages) were used. Immunostaining was performed using the alkaline phosphatase-antialkaline phosphatase technique as previously described (14). Briefly, cytospins were incubated with primary mouse antihuman monoclonal antibodies (MBP was kindly provided by Dr R Moqbel, and neutrophil elastase, CD3 and CD68 were from Dako Diagnostics, Canada) at $4^{\circ} \mathrm{C}$ overnight. Sections were then incubated with rabbit antimouse immunoglobulin as a secondary antibody, followed by streptavidin or alkaline phosphatase-antialkaline phosphatase complex. The reaction was visualized with fast red alkaline phosphatase substrate.

\section{In situ hybridization}

To detect IL-4 and IL-5 messenger RNA (mRNA) in cytospins, radiolabelled complementary riboprobes (complementary antisense RNA) were used. The complementary DNA sequences for IL-4 and IL-5 were inserted into pGEM vectors (Promega, USA), grown in Escherichia coli, and linearized with the appropriate enzymes. Before in situ hybridization, in vitro transcription to generate sense and antisense probes was performed in the presence of ${ }^{35}$ S-uridine triphosphate and the appropriate T7 or SP6 polymerases as previously reported (15). Cytospins were permeabilized, 


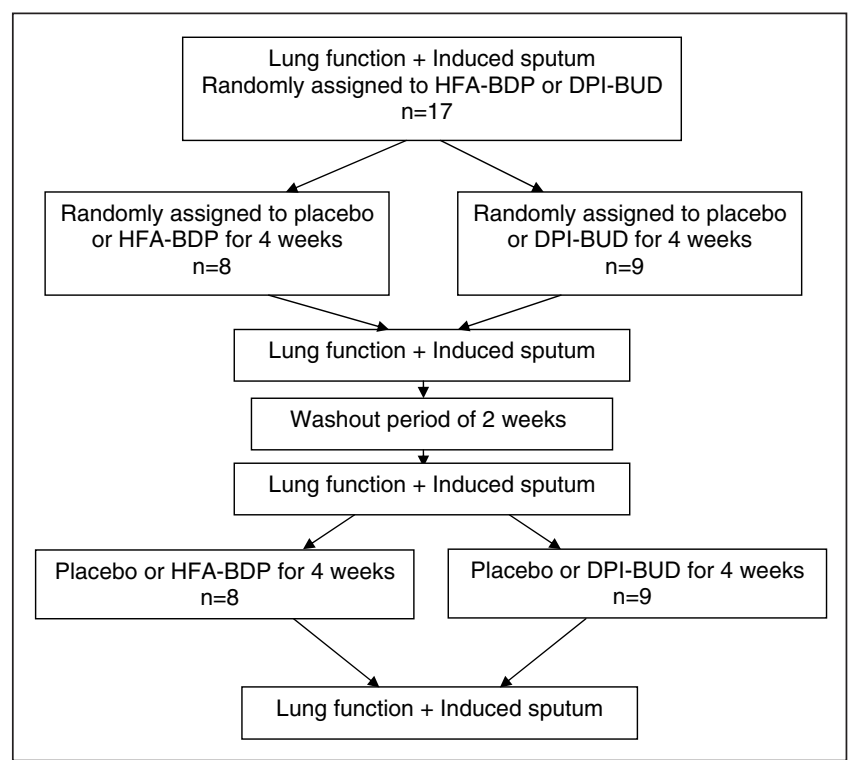

Figure 1) Schematic representation of the study design. DPI-BUD Budesonide in a dry powder inhaler; HFA-BDP Hydrofluoroalkane formulation of beclomethasone dipropionate

treated with acetic anhydride and triethanolamine to reduce nonspecific binding, and prehybridized in formamide at $42^{\circ} \mathrm{C}$. ${ }^{35} \mathrm{~S}$-labelled antisense probes were used $\left(10^{6} \mathrm{cpm} / \mathrm{section}\right)$, followed by high-stringency posthybridization washings. Unhybridized, single-stranded RNA was removed by treating the preparations with RNase. After posthybridization, the slides were immersed in emulsion fluid and exposed for 10 to 14 days. The autoradiograms were developed, fixed and counterstained with hematoxylin.

\section{Quantification}

Sputum samples containing less than 20\% of contaminating squamous cells were considered suitable for analysis. The number of positive cells expressing cell markers (MBP, neutrophil elastase, CD3 and CD68 immunoreactivity) and IL-4 and IL-5 mRNA were counted. Samples were counted twice. The withinobserver coefficient of variation for repeated measures was less than $5 \%$.

\section{Data analysis and statistics}

To compare the effects of active treatment versus placebo and the effects of HFA-BDP versus DPI-BUD, differences were calculated by using the response after treatment (either active or placebo) minus the value at baseline preceding that period. This was tested by comparing the differences with an ANOVA model (SAS PROC GLM [SAS Institute, USA]) with terms for group (HFA-BDP versus DPI-BUD), treatment (active versus placebo) and group by treatment interaction considered to be fixed effects, and with a term for subject within group considered to be a random effect. $\mathrm{P}<0.05$ was considered to be statistically significant. Differences are expressed as the percentage of positive cells per total cells. All values are given as means \pm SEM if not otherwise stated. Power calculations showed that the sample size was strong enough (over 80\%) to detect significant differences between groups, with a probability of error (alpha) of 0.05 and a known standard deviation for eosinophils and IL-4. Unfortunately, due to higher variability of measurements, a weaker power was observed for neutrophils, macrophages, lymphocytes and IL-5.
TABLE 1

Patient group characteristics

\begin{tabular}{|c|c|c|c|}
\hline & $\begin{array}{c}\text { HFA-BDP } \\
\text { group }(n=8)\end{array}$ & $\begin{array}{c}\text { DPI-BUD } \\
\text { group }(n=9)\end{array}$ & $\mathbf{P}$ \\
\hline Sex (men/women) & $5 / 3$ & $2 / 7$ & \\
\hline Age (years) & $36.8 \pm 2.9$ & $34.9 \pm 2.9$ & NS \\
\hline $\mathrm{FEV}_{1}(\% \text { of predicted })^{*}$ & $83.4 \pm 5.1$ & $90.2 \pm 2.9$ & NS \\
\hline $\mathrm{FEV}_{1}(\mathrm{~L})^{*}$ & $3.1 \pm 0.3$ & $2.9 \pm 0.3$ & \\
\hline
\end{tabular}

${ }^{*}$ Forced expiratory volume in $1 \mathrm{~s}\left(F E V_{1}\right)$ values before the beginning of the study. DPI-BUD Budesonide in a dry powder inhaler; HFA-BDP Hydrofluoroalkane formulation of beclomethasone dipropionate; NS Not significant

TABLE 2

Baseline values of sputum inflammatory markers measured in early and late induced-sputum samples

\begin{tabular}{lrrrrr}
\hline & \multicolumn{2}{c}{ HFA-BDP } & group & & \multicolumn{2}{c}{ DPI-BUD group } \\
\cline { 2 - 3 } \cline { 6 - 6 } & $\begin{array}{c}\text { Early } \\
\text { sputum }\end{array}$ & $\begin{array}{c}\text { Late } \\
\text { sputum }\end{array}$ & & $\begin{array}{c}\text { Early } \\
\text { sputum }\end{array}$ & $\begin{array}{c}\text { Late } \\
\text { sputum }\end{array}$ \\
\hline Eosinophils (\%) & $8.3 \pm 1.9$ & $6.3 \pm 1.5$ & & $9.7 \pm 2.6$ & $7.7 \pm 2.2$ \\
Neutrophils (\%) & $27.4 \pm 5.9$ & $28.3 \pm 6.5$ & & $34.8 \pm 4.5$ & $31.7 \pm 4.8$ \\
Lymphocytes (\%) & $1.2 \pm 0.5$ & $1.4 \pm 0.7$ & & $0.5 \pm 0.2$ & $0.6 \pm 0.2$ \\
Macrophages (\%) & $54.7 \pm 5.5$ & $51.4 \pm 9.2$ & & $39.5 \pm 4.8$ & $43.3 \pm 5.7$ \\
IL-4-positive cells (\%) & $7.4 \pm 0.5$ & $6.7 \pm 0.6$ & & $7.0 \pm 1.1$ & $4.5 \pm 0.4$ \\
IL-5-positive cells (\%) & $5.7 \pm 0.6$ & $5.6 \pm 0.8$ & & $8.2 \pm 1.3$ & $7.5 \pm 1.4$ \\
\hline
\end{tabular}

DPI-BUD Budesonide in a dry powder inhaler; HFA-BDP Hydrofluoroalkane formulation of beclomethasone dipropionate; IL Interleukin

\section{RESULTS}

Patient characteristics and lung function

Table 1 summarizes the clinical characteristics of both treatment groups. Both therapies led to an increase in forced expiratory volume in $1 \mathrm{~s}\left(\mathrm{FEV}_{1}\right)$ compared with placebo, but the changes did not reach statistical significance; following four weeks of treatment with HFA-BDP, the $\mathrm{FEV}_{1}$ increased by $0.18 \pm 0.1 \mathrm{~L}(7.5 \% \pm 4.0 \%)$ from the baseline value. Similarly, treatment with DPI-BUD for four weeks led to an increase in $\mathrm{FEV}_{1}$ of $0.17 \pm 0.08 \mathrm{~L}(9.0 \% \pm 3.8 \%)$. Placebo led to increases in $\mathrm{FEV}_{1}$ of $0.07 \pm 0.06 \mathrm{~L}(3 \% \pm 2.4 \%)$ and $0.003 \pm 0.03 \mathrm{~L}$ $(0.3 \% \pm 1.3 \%)$ in the HFA-BDP and DPI-BUD groups, respectively. In addition, no significant difference was found between groups in the change in $\mathrm{FEV}_{1}$ after treatment.

\section{Inflammatory cell changes}

Baseline values of inflammatory cells measured in the early and late induced sputa before active treatment are summarized in Table 2. No significant differences were detected in any parameters between groups. Treatment with HFA-BDP significantly decreased eosinophils (MBP immunoreactive cells) in both early $(-7.3 \% \pm 1.7 \%)$ and late induced-sputum samples $(-4.3 \% \pm 0.8 \%)$ compared with placebo $(-0.4 \% \pm 0.1 \%$ and $0.9 \% \pm 1.5 \% ; \mathrm{P}<0.05)$ (Figures 2A, B, E and F; Table 3). On the other hand, DPI-BUD had a significant effect only on early induced-sputum samples compared with placebo $(-6.4 \% \pm 2.1 \%$ on active treatment versus $1.9 \% \pm 1.2 \%$ on placebo; $\mathrm{P}<0.05)$, but not in late induced-sputum samples $(-3.5 \% \pm 1.8 \%$ on active treatment versus $-3.1 \% \pm 1.9 \%$ on placebo) (Figures 2C, D, G and H; Table 3). Despite the small sample size, the power to detect a significant difference in the eosinophil data was over $80 \%$.

Both drugs significantly increased the percentage of neutrophils (elastase immunoreactive cells) in early induced-sputum samples compared with placebo $(\mathrm{P}<0.05)$ (Table 3). However, due to the high variability of the neutrophil data, the power 


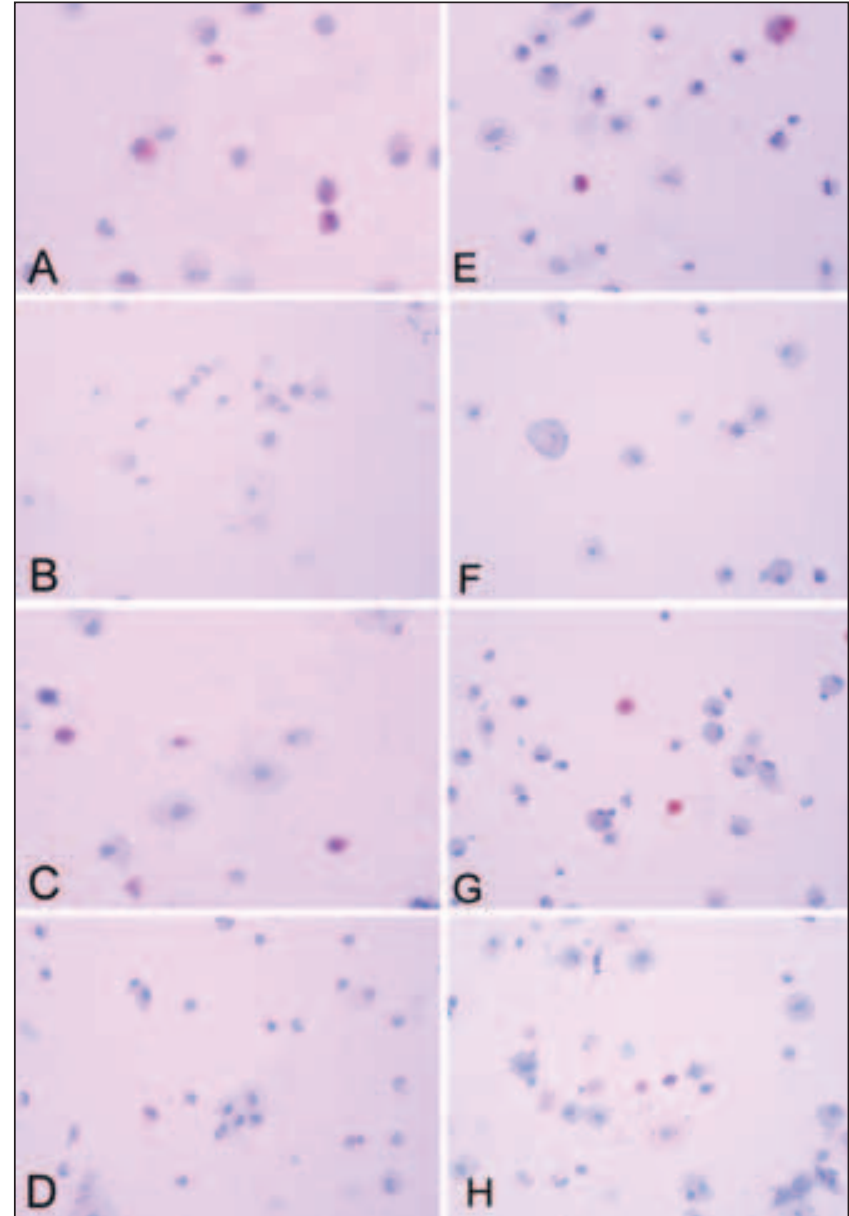

Figure 2) Representative examples of the immunocytochemistry of early (A to $\mathrm{D})$ and late $(\mathrm{E}$ to $\mathrm{H})$ induced-sputum samples showing eosinophils (red) before (A, C, E and G) and after (B, D, F and H) treatment with either a hydrofluoroalkane formulation of beclomethasone dipropionate ( $\mathbf{A}, \mathbf{B}, \mathbf{E}$ and $\mathbf{F}$ ) or budesonide in a dry powder inhaler $(\mathbf{C}, \mathbf{D}, \mathbf{G}$ and $\mathbf{H})$. Original magnification $\times 200$

was too weak to firmly confirm the significance of this change. This effect was much larger with HFA-BDP $(13.5 \% \pm 6.0 \%$ on active treatment versus $-11.4 \% \pm 8.1 \%$ on placebo) than with DPI-BUD $(3.8 \% \pm 4.9 \%$ on active treatment versus $0.2 \% \pm 6.1 \%$ on placebo). However, this interaction was not statistically significant. Also, no significant change was observed in neutrophils in late induced-sputum samples.

The numbers of lymphocytes (CD3 immunoreactive cells) and macrophages (CD68 immunoreactive cells) were not significantly changed after treatment with HFA-BDP or DPI-BUD compared with placebo in early and late inducedsputum samples (Table 3 ).

\section{Changes of inflammatory gene expression}

Baseline values of inflammatory gene expression measured in the early and late induced sputa before active treatment are summarized in Table 2. No significant differences were observed between groups. In early induced-sputum samples, IL-4 and IL-5 mRNA expression were significantly decreased after treatment with both HFA-BDP $(-3.9 \% \pm 0.7 \%$ on active treatment versus $1.1 \% \pm 0.8 \%$ on placebo, and $-2.4 \% \pm 0.3 \%$ on active treatment versus $-0.5 \% \pm 1.0 \%$ on placebo, respectively;
TABLE 3

Changes in inflammatory cells

\begin{tabular}{llrrrr}
\hline Cell type & $\begin{array}{c}\text { Sputum } \\
\text { sample }\end{array}$ & $\begin{array}{c}\text { HFA-BDP } \\
\text { active }\end{array}$ & $\begin{array}{c}\text { HFA-BDP } \\
\text { placebo }\end{array}$ & $\begin{array}{c}\text { DPI-BUD } \\
\text { active }\end{array}$ & $\begin{array}{r}\text { DPI-BUD } \\
\text { placebo }\end{array}$ \\
\hline Eosinophils & Early & $-7.3 \pm 1.7$ & $-0.4 \pm 2.1$ & $-6.4 \pm 2.1$ & $1.9 \pm 1.2$ \\
& Late & $-4.3 \pm 0.8$ & $0.9 \pm 1.5$ & $-3.5 \pm 1.8$ & $-3.1 \pm 1.9$ \\
Neutrophils & Early & $13.5 \pm 6.0$ & $-11.4 \pm 8.1$ & $3.8 \pm 4.9$ & $0.2 \pm 6.1$ \\
& Late & $7.1 \pm 5.8$ & $-3.9 \pm 5.9$ & $1.8 \pm 3.5$ & $6.3 \pm 5.9$ \\
Lymphocytes & Early & $-0.5 \pm 0.4$ & $0.9 \pm 0.7$ & $0.7 \pm 0.5$ & $0.0 \pm 0.5$ \\
& Late & $-0.1 \pm 0.5$ & $0.1 \pm 0.5$ & $0.9 \pm 0.6$ & $1.4 \pm 0.3$ \\
Macrophages & Early & $-11.1 \pm 4.8$ & $3.7 \pm 8.8$ & $-0.7 \pm 6.0$ & $-2.6 \pm 5.4$ \\
& Late & $-7.7 \pm 10.4$ & $0.9 \pm 3.9$ & $0.5 \pm 4.7$ & $5.4 \pm 4.9$
\end{tabular}

Changes in the percentage of positive cells with respect to total cells. Values are given as means \pm SEM. DPI-BUD Budesonide in a dry powder inhaler HFA-BDP Hydrofluoroalkane formulation of beclomethasone dipropionate

\section{TABLE 4}

Changes in inflammatory cytokine expression

\begin{tabular}{lccrrr}
\hline Cytokine & $\begin{array}{c}\text { Sputum } \\
\text { sample }\end{array}$ & $\begin{array}{c}\text { HFA-BDP } \\
\text { active }\end{array}$ & $\begin{array}{c}\text { HFA-BDP } \\
\text { placebo }\end{array}$ & $\begin{array}{c}\text { DPI-BUD } \\
\text { active }\end{array}$ & $\begin{array}{c}\text { DPI-BUD } \\
\text { placebo }\end{array}$ \\
\hline Interleukin-4 & Early & $-3.9 \pm 0.7$ & $1.1 \pm 0.8$ & $-3.5 \pm 0.7$ & $1.0 \pm 1.0$ \\
& Late & $-3.5 \pm 0.6$ & $0.0 \pm 0.7$ & $-0.7 \pm 0.7$ & $1.3 \pm 0.5$ \\
Interleukin-5 & Early & $-2.4 \pm 0.3$ & $-0.5 \pm 1.0$ & $-4.8 \pm 1.3$ & $-1.7 \pm 1.2$ \\
& Late & $-3.1 \pm 0.6$ & $0.4 \pm 0.6$ & $-0.7 \pm 1.1$ & $-0.6 \pm 0.7$ \\
\hline
\end{tabular}

Changes in the percentage of positive cells with respect to total cells. Values are given as means \pm SEM. DPI-BUD Budesonide in a dry powder inhaler, HFA-BDP Hydrofluoroalkane formulation of beclomethasone dipropionate

$\mathrm{P}<0.01)$ and DPI-BUD $(-3.5 \% \pm 0.7 \%$ on active treatment versus $1.0 \% \pm 1.0 \%$ on placebo, and $-4.8 \% \pm 1.3 \%$ on active treatment versus $-1.7 \% \pm 1.2 \%$ on placebo, respectively; $\mathrm{P}<0.01$ ) compared with placebo (Table 4).

In late induced-sputum samples, both HFA-BDP and DPI-BUD significantly decreased the expression of IL-4 mRNA compared with placebo $(\mathrm{P}<0.01)$ (Table 4). However, this effect was significantly $(\mathrm{P}<0.05$, power of $81 \%)$ more pronounced with HFA-BDP $(-3.5 \% \pm 0.6 \%$ on active treatment versus $0.0 \% \pm 0.7 \%$ on placebo) than with DPI-BUD $(-0.7 \% \pm 0.7 \%$ on active treatment versus $1.3 \% \pm 0.5 \%$ on placebo). Despite a weak power for the IL-5 data, treatment with HFA-BDP clearly decreased IL-5 mRNA expression in late induced-sputum samples compared with placebo $(-3.1 \% \pm 0.6 \%$ versus $0.4 \% \pm 0.6 \% ; \mathrm{P}<0.01)$, whereas DPI-BUD had no significant effect $(-0.7 \% \pm 1.1 \%$ on active treatment versus $-0.6 \% \pm 0.7 \%$ on placebo) (Table 4 ).

\section{DISCUSSION}

The present study is the first to directly compare the antiinflammatory effect of an HFA-formulated corticosteroid with a DPI corticosteroid in induced sputum collected either early or later after the initiation of sputum induction. In the present study, we found that an HFA-formulated inhaled corticosteroid (HFA-BDP) significantly reduced eosinophilic inflammation and the expression of the T helper 2-type cytokines IL-4 and IL-5 in both early and late induced sputa in bronchial asthma, whereas a DPI (DPI-BUD) was mostly effective in early induced sputum.

In the present study, induced-sputum samples were used to investigate inflammatory markers because induced sputum is a reliable, noninvasive, safe method for asthmatic patients (16). Although it has been postulated that inflammatory cells found in the early induced sputum reflect central airway secretions, whereas inflammatory cells found in late induced sputum reflect 
secretions from the more distal airways (10), the precise anatomical compartment from which inflammatory cells found in induced sputum originate is not clearly defined. However, markers of alveolar secretions, such as surfactant protein A, can be detected in late induced-sputum samples, suggesting that the more distal airways and alveolar compartments may be represented in late induced-sputum samples more than in early induced-sputum samples (10). In 2001, Alexis et al (17) used a radiolabelled aerosol bolus delivery technique to show that the central airways are the major site or origin of induced sputum. Thus, although the inflammatory cells detected in the early and late samples both likely reflect a central airway origin, there is clearly variability in the cellular composition, depending on the duration and timing of the sputum induction procedure, and perhaps in part due to the more distal contribution in the late induced-sputum samples. It is clear that the timing of sputum collection after induction is crucial. Timing of sputum collection may profoundly affect results when comparing treatment effects.

Previous studies have shown that inflammation in bronchial asthma extends to the peripheral airways (1). Although inhaled corticosteroids have been shown to successfully suppress airway inflammation, they are mainly deposited in the central airways (2-4). New HFA-formulated inhaled corticosteroids are effective in controlling asthma and, because of their small particle size, they can reach more distal airways (5). However, the antiinflammatory effect of HFA-formulated corticosteroids has not yet been directly compared with traditionally formulated corticosteroids. One study (18) investigating the effects of HFA flunisolide on peripheral and central airway inflammation in asthmatic patients using lung biopsies has shown that HFA flunisolide reduces eosinophils, as well as IL-5 and eotaxin expression, in both the central and peripheral airways.

In the present study, our findings that HFA-BDP significantly reduced eosinophils, as well as IL-4 and IL-5, in both early and late induced-sputum samples supports these data. In contrast, DPI-BUD had a significant effect in early induced-sputum samples only. These findings suggest that HFA-BDP may be able to suppress eosinophilic inflammation more extensively in the lung than DPI-BUD. The expression of IL-4 and IL-5 in induced-sputum cells was previously studied by Olivenstein et al (19). The majority of cells expressing IL-4 and IL-5 were CD3positive cells. Although the numbers of lymphocytes did not change significantly after corticosteroid treatment, IL-4 and IL-5 mRNA expression was decreased, thus indicating that inflammatory gene expression was inhibited in lymphocytes. However, part of the decrease in IL-4- and IL-5-positive cells may also be due to the reduction in the numbers of eosinophils. By treating mildly asthmatic patients with inhaled corticosteroids, the number of cells expressing IL-4 and IL-5 in early induced sputum was lowered by approximately 50\%. This significant decrease may be clinically relevant; however, our short treatment course did not allow us to detect any clinical outcomes such as decreases in symptoms and exacerbations.

Both HFA-BDP and DPI-BUD led to a significant increase in neutrophils in early induced-sputum samples, without any clinical sign of infection. This is not surprising because it has been shown that corticosteroids increase neutrophils by improving their survival and inducing neutrophil-attracting mediators such as IL-8 $(20,21)$. Moreover, in a previous study (18), a significant increase in the numbers of neutrophils in biopsies of peripheral and central airways was observed after treatment with another HFA-formulated corticosteroid.
Some studies (2,22-24) have reported a decrease in lymphocytes following corticosteroid treatment, whereas others have not. In the present study, no significant change was found in the number of lymphocytes after HFA-BDP or DPI-BUD treatment. This finding could be due to the short time frame and small number of patients in the study. Lymphocyte numbers are usually very low in induced-sputum samples, making detection of differences more difficult.

Although $\mathrm{FEV}_{1}$ increased to a similar extent after treatment with either HFA-BDP or DPI-BUD, this effect did not reach statistical significance. Because our patients were well controlled, intermittent, mild asthmatics, no significant differences were expected. Both drugs reduced the eosinophilic inflammation and the expression of IL-4 and IL-5 to the same extent in the early induced sputum. These observations suggest that the doses used are equipotent on an anti-inflammatory basis in the central airways. Despite the small sample size, our study was powerful enough to make conclusions on the effectiveness of inhaled corticosteroids on the main outcomes investigated.

\section{CONCLUSIONS}

The present study showed that HFA-BDP is able to reduce eosinophilic inflammation and cytokine gene expression in early and late induced sputa, whereas a traditionally formulated inhaled corticosteroid (DPI-BUD) had an effect mostly in early induced sputum. Therefore, by more extensively suppressing eosinophilic inflammation in the lung, HFA-formulated corticosteroids may be better able to control bronchial asthma than traditionally formulated corticosteroids. The data in the present study also suggest that the timing of sputum collection after induction leads to representation of different airway compartments.

ACKNOWLEDGEMENTS: Thanks to Scott McRae, Bruce Ekholm and Heberto Ghezzo for consultation on the statistical methods. Hans-Peter Hauber is a recipient of a GSK/CLA/CIHR fellowship.

FUNDING: Supported by 3M Pharmaceuticals, London, Ontario.

\section{REFERENCES}

1. Hamid Q, Song Y, Kotsimbos TC, et al. Inflammation of small airways in asthma. J Allergy Clin Immunol 1997;100:44-51.

2. Booth H, Richmond I, Ward C, Gardiner PV, Harkawat R, Walters EH. Effect of high dose inhaled fluticasone propionate on airway inflammation in asthma. Am J Respir Crit Care Med 1995;152:45-52.

3. Djukanovic R, Wilson JW, Britten KM, et al. Effect of an inhaled corticosteroid on airway inflammation and symptoms in asthma. Am Rev Respir Dis 1992;145:669-74.

4. Esmailpour N, Hogger P, Rabe KF, Heitmann U, Nakashima M, Rohdewald P. Distribution of inhaled fluticasone propionate between human lung tissue and serum in vivo. Eur Respir J 1997;10:1496-9.

5. Leach CL, Davidson PJ, Hasselquist BE, Boudreau RJ. Lung deposition of hydrofluoroalkane-134a beclomethasone is greater than that of chlorofluorocarbon fluticasone and chlorofluorocarbon beclomethasone: A cross-over study in healthy volunteers. Chest 2002;122:510-6.

6. Hirst PH, Bacon RE, Pitcairn GR, Silvasti M, Newman SP. A comparison of the lung deposition of budesonide from Easyhaler, Turbuhaler and pMDI plus spacer in asthmatic patients. Respir Med 2001;95:720-7.

7. Borgstrom L. Deposition patterns with Turbuhaler. J Aerosol Med 1994;7(Suppl 1):S49-S53.

8. Gross G, Thompson PJ, Chervinsky P, Vanden Burgt J. Hydrofluoroalkane-134a beclomethasone dipropionate, 400 microg, is as effective as chlorofluorocarbon beclomethasone dipropionate, 800 microg, for the treatment of moderate asthma. Chest 1999;115:343-51. 
9. Busse WW, Brazinsky S, Jacobson K, et al. Efficacy response of inhaled beclomethasone dipropionate in asthma is proportional to dose and is improved by formulation with a new propellant. J Allergy Clin Immunol 1999;104:1215-22.

10. Gershman NH, Liu H, Wong HH, Liu JT, Fahy JV. Fractional analysis of sequential induced sputum samples during sputum induction: Evidence that different lung compartments are sampled at different time points. J Allergy Clin Immunol 1999;104:322-8.

11. Taha R, Hamid Q, Olivenstein R. Fractional analysis of Th2-type cytokines in sequential samples of induced sputum. Can Respir J 2004;11:146-50.

12. Reichel W, Dahl R, Ringdal N, Zetterstrom O, van den Elshout FJ, Laitinen LA. Extrafine beclomethasone dipropionate breath-actuated inhaler (400 micrograms/day) versus budesonide dry powder inhaler (800 micrograms/day) in asthma. Int J Clin Pract 2001;55:100-6.

13. Pizzichini E, Pizzichini MM, Efthimiadis A, et al. Indices of airway inflammation in induced sputum: Reproducibility and validity of cell and fluid-phase measurements. Am J Respir Crit Care Med 1996;154:308-17.

14. Hamid Q, Springall DR, Riveros-Moreno V, et al. Induction of nitric oxide synthase in asthma. Lancet 1993;342:1510-3.

15. Hamid Q, Wharton J, Terenghi G, et al. Localization of atrial natriuretic peptide mRNA and immunoreactivity in the rat heart and human atrial appendage. Proc Natl Acad Sci USA 1987;84:6760-4.

16. Fahy JV, Boushey HA, Lazarus SC, et al; NHLBI Asthma Clinical Research Network. Safety and reproducibility of sputum induction in asthmatic subjects in a multicenter study. Am J Respir Crit Care Med 2001;163:1470-5.
17. Alexis NE, Hu SC, Zeman K, Alter T, Bennett WD. Induced sputum derives from the central airways: Confirmation using a radiolabeled aerosol bolus delivery technique. Am J Respir Crit Care Med 2001;164:1964-70.

18. Hauber HP, Gotfried M, Newman K, et al. Effect of HFA-flunisolide on peripheral lung inflammation in asthma. J Allergy Clin Immunol 2003;112:58-63.

19. Olivenstein R, Taha R, Minshall EM, Hamid QA. IL-4 and IL-5 mRNA expression in induced sputum of asthmatic subjects: Comparison with bronchial wash. J Allergy Clin Immunol 1999; 103:238-45.

20. Cox G. Glucocorticoid treatment inhibits apoptosis in human neutrophils. Separation of survival and activation outcomes. J Immunol 1995;154:4719-25.

21. Fukakusa M, Bergeron C, Tulic MK, et al. Oral corticosteroids decrease eosinophil and CC chemokine expression but increase neutrophil, IL-8, and IFN-gamma-inducible protein 10 expression in asthmatic airway mucosa. J Allergy Clin Immunol 2005;115:280-6.

22. Holm AF, Godthelp T, Fokkens WJ, et al. Long-term effects of corticosteroid nasal spray on nasal inflammatory cells in patients with perennial allergic rhinitis. Clin Exp Allergy 1999;29:1356-66.

23. Burke C, Power CK, Norris A, Condez A, Schmekel B, Poulter LW. Lung function and immunopathological changes after inhaled corticosteroid therapy in asthma. Eur Respir J 1992;5:73-9.

24. Boulet LP, Turcotte H, Laviolette M, et al. Airway hyperresponsiveness, inflammation, and subepithelial collagen deposition in recently diagnosed versus long-standing mild asthma. Influence of inhaled corticosteroids. Am J Respir Crit Care Med 2000;162:1308-13. 


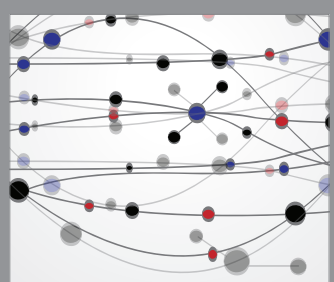

The Scientific World Journal
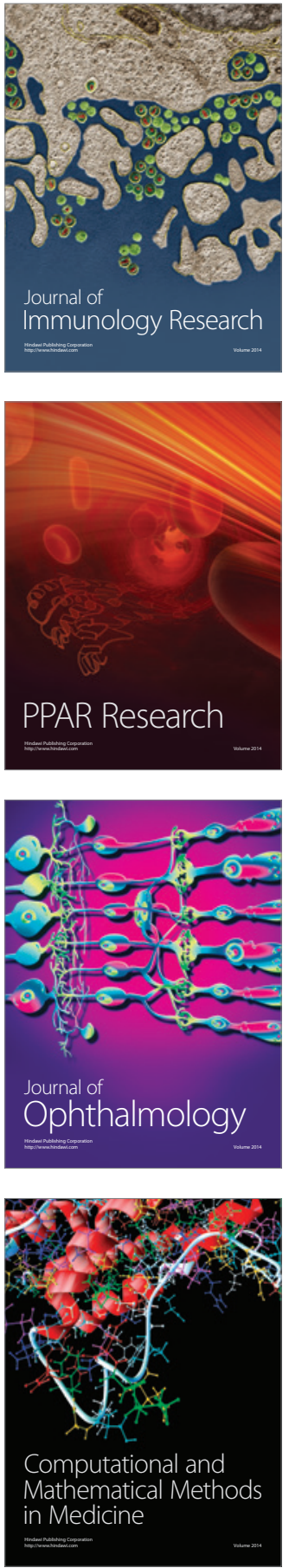

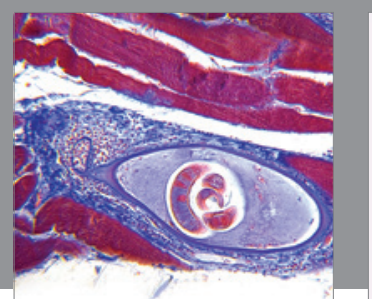

Gastroenterology Research and Practice

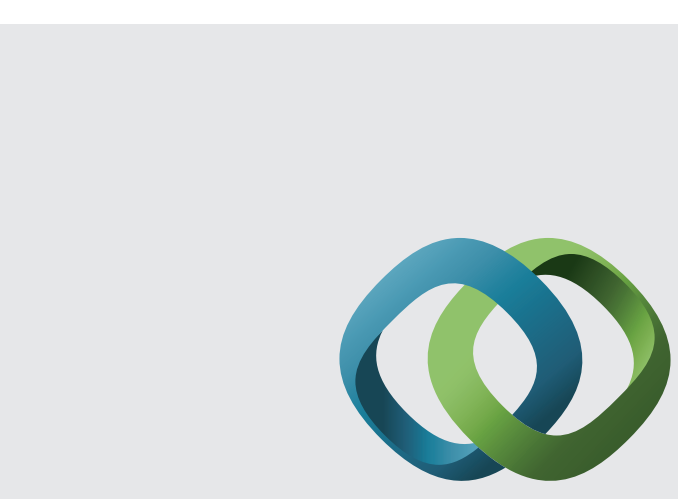

\section{Hindawi}

Submit your manuscripts at

http://www.hindawi.com
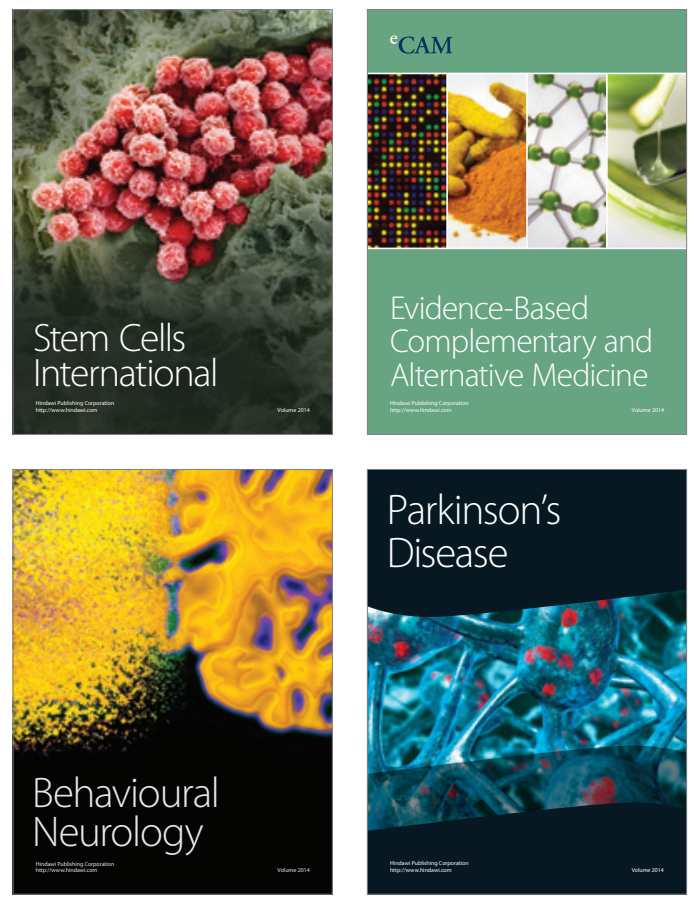
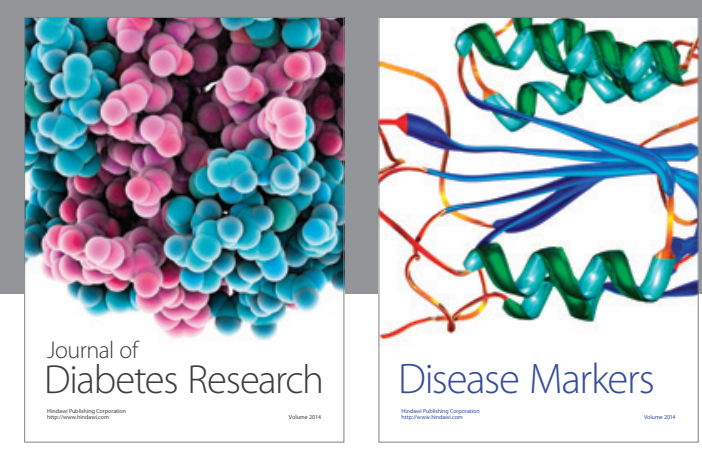

Disease Markers
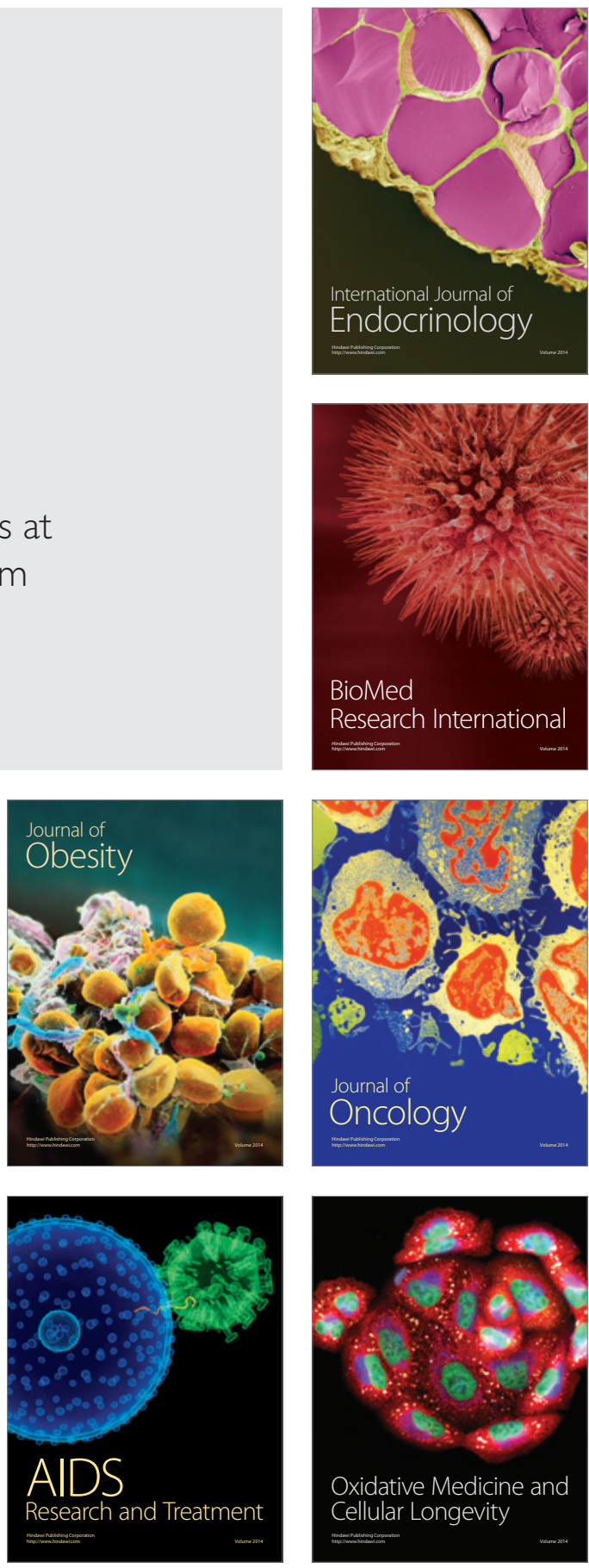